\title{
Effect of Interlamelar Composition on ZnAI Hydrotalcites: Synthesis and Characterization
}

\author{
Selina Ilunakan Omonmhenle, Doctor of Chemistry \\ Department of Chemistry, Faculty of Physical Sciences, \\ University of Benin, Nigeria \\ Ian James Shannon, Doctor of Chemistry \\ School of Chemistry, University of Birmingham, \\ Edgbaston, United Kingdom
}

Doi: 10.19044/esj.2019.v15n12p307 URL:http://dx.doi.org/10.19044/esj.2019.v15n12p307

\begin{abstract}
The preparation and characterisation of $\mathrm{ZnAl}$ hydrotalcites with varying interlamellar anions have been investigated. The synthesis was achieved through co-precipitation at low supersaturation, accompanied by hydrothermal curing at $110^{\circ} \mathrm{C}$ for $18 \mathrm{~h}$. A range of techniques such as XRD, XRF, FT-IR, TG-DTA, SEM, and surface area were utilised to investigate the effect that the varying of interlamellar anions impacted on the hydrotalcites. The x-ray diffraction and FT-IR data confirmed that the samples synthesised were hydrotalcites with the intercalation of various anions of interest. The nitrate hydrotalcite showed less stacking order with highest basal spacing, while the carbonate hydrotalcite showed smallest unit cell, more regular stacked sheets, and denser nanoparticles. Thermal results are identical in all hydrotalcite studied but with variance in the temperature of the decomposition stages. Suraface area and the scanning electron microscopy analysis demonstrated that the composition of interlamella region influences the structure and properties of the synthesised hydrotalcites.
\end{abstract}

Keywords: Hydrotalcite, Gallery space, Hydrothermal curing, Decarbonated water, and Positive charge sheets

\section{Introduction}

Hydrotalcites (HTs) are natural or synthetic lamella hydroxides also named as layered double hydroxides (LDHs) (Cavani, Trifiro, \& Vaccari, 1991; Rives, 2001; Omonmhenle \& Shannon, 2016). They exhibit a remarkable broad spectrum of properties and allow modification of chemical, structural composition, and/or structural modification of the interlamellar composition. Layered double hydroxides or hydrotalcites have existed for a 
long time but only recently have they attracted recognition because they possess potential applications (You et al., 2001; Pshinko, 2013). This is as a result of their very simplified structure, flexible composition, and ease of synthesis. The major advantage of these materials is the tunable ratio and disposition of divalent and trivalent metal cations and varied interlayer structure. This class of intercalated compounds can be expressed as $\left[\left[\mathrm{M}^{2+}{ }_{1-}\right.\right.$ $\left.\left.{ }_{x} \mathrm{M}^{3+}{ }_{x}(\mathrm{OH})_{2}\right]\left[\mathrm{A}^{\mathrm{n}-}{ }_{\mathrm{x} / \mathrm{n}}\right)\right] \cdot \mathrm{mH}_{2} \mathrm{O}$, where $\mathrm{M}^{2+}$ and $\mathrm{M}^{3+}$ are divalent and trivalent metals in the positive charge sheets (Basahel et al., 2014). The ratio $\mathrm{x}$ is the mole ratio and it varies between 0.2 and 0.33 (Cavani et al., 1991; Birgul \& Ahmet, 2012). Thus, ' $n$ ' and ' $m$ ' are charge on the anion $A$ and water of crystallisation within the inter lamella respectively (Evans \& Duan, 2006; Elgiddawy et al., 2017). The increased attraction to the hydrotalcites is based on the large number of potential applications for which these materials can be set (Cavani et al., 1991; Sulekha, 2016). There are several combinations of divalent/trivalent cations and very many anions (El Hassani et al., 2017) that can be intercalated into the gallery of the hydrotalcites. The characteristics of the interlayer anions can affect the orientation of the anions within the layers. This in turn can influence the interactions of anions with the hydroxide layers, thus influencing the overall properties and specific use of the hydrotalcites (Zümreoglu-Karan \& Ay, 2012). The aim of this study is to synthesise hydrotalcites with $\mathrm{Zn} / \mathrm{Al}$ in the positive hydroxide layers but varying the interlamellar compositions, and then to characterise them with a range of techniques to ascertain the effect the differences of interlamellar anions within the gallery space would have on the specific properties of the hydrotalcites.

\section{Experimental}

\section{Reagents}

Zinc nitrate hexahydrate $(98 \%)$ and Aluminium nitrate nonahydrate (98\%) were gotten from Sigma-Aldrich, Germany. Zinc chloride (98\%), sodium carbonate $(99 \%)$, and sodium chloride were purchased from SigmaAldrich, USA. Sodium nitrate was procured from Sigma-Aldrich, Japan, and Sodium hydroxide was obtained from Fisher Scientific, UK. Aluminium chloride was bought from BDH laboratory supplies, England. All reagents were analytical grade and were used as received.

\section{Synthesis of ZnAl-hydrotalcites}

Preparation of $\mathrm{ZnAl}$-hydrotalcites with varying interlayer anions were carried out by co-precipitation method after the procedure described by Omonmhenle and Shannon 2016. Three sets of two solutions were prepared. The first solution consisted of Zinc nitrate hexahydrate and aluminium nitrate nonahydrate, or aluminium chloride and Zinc chloride, while the third 
consisted of Zinc nitrate hexahydrate and aluminium nitrate nonahydrate dissolved in deionised water or deionised decarbonated water at $\mathrm{Zn} / \mathrm{Al}$ molar ratio of 2:1. The second solutions are composed of sodium hydroxide and sodium carbonate, sodium hydroxide and sodium chloride, or sodium hydroxide and sodium nitrate. These were added such that each base solution is having molar ratios equivalent to $4 \mathrm{M}$ (carbonate hydrotalcite), $3.5 \mathrm{M}$ for the chloride and $3 \mathrm{M}$ for the nitrate version. The $\mathrm{pH}$ of the resulting solutions were $10.28 \pm 0.36$ (carbonate), $8.08 \pm 0.07$ (nitrate), and 6.3 \pm 0.10 . For each set, the two solutions were allowed to flow dropwise into a reactor at the same time and at constant flow rate maintaining the solution $\mathrm{pH}$ for each of the hydrotalcite set. Each mother slurry at the end of the flow was allowed to stir for a further 30 minutes after which each of them were aged in a Nalgene Teflon closed bottles for $18 \mathrm{~h}$ and at $110^{\circ} \mathrm{C}$. The obtained gelatinous precipitates were filtered, washed several times, and dried at $60^{\circ} \mathrm{C}$ overnight. Deionised decarbonated water was used for the chloride and nitrate forms of hydrotalcites. The derived samples were designated as $\mathrm{Zn}_{2} \mathrm{Al}-\mathrm{A}$, where $\mathrm{A}$ stands for $\mathrm{CO}_{3}{ }^{2-}, \mathrm{Cl}^{-}$and $\mathrm{NO}_{3}{ }^{-}$respectively.

\section{Characterization}

X-ray diffraction was performed with a Bruker D8 ADVANCE X-ray diffractometer to identify the hydrotalcites. The patterns were collected with $\mathrm{CuK} \alpha_{1}$ radiation $(\lambda=1.54056 \AA)$ in a reflection mode at $0.2^{\circ}$ from $5-70^{\circ}(2 \theta)$ using accelerating voltage of $40 \mathrm{kV}$ and $30 \mathrm{~mA}$ current at room temperature (Omonmhenle \& Shannon 2016).

The chemical composition of the as-synthesised hydrotalcites were determined with a Bruker S8 TIGER x-ray fluorescence spectrometer using the fused beads method to measure the major oxides. The hydrotalcites were formed into fused beads by mixing them with a flux (di-lithium tetraborate in a ratio of $1.0 \mathrm{~g}$ of as-synthesised hydrotalcite in $10 \mathrm{~g}$ of the flux at $1250^{\circ} \mathrm{C}$, melting the mixture in a platimium crucible to form the beads. The beads were used for the XRF evaluation without any additional sample preparation.

A Varian 660 FT-IR spectrometer was employed to establish the anions that were present in between the layers of the various as-synthesised hydrotalcites. The (ATR) method was used with a diamond sample holder, collecting 16 scans in the range of $700-4000 \mathrm{~cm}^{-1}$ with a resolution of $4 \mathrm{~cm}^{-1}$ and sensitivity of 1 .

Simultaneous thermogravimetric (TG) and differential thermal analyses (DTA) were performed with a Netzsch STA 449 FI Jupiter® apparatus, coupled with a quadrupole mass spectrometer (Netzsch QMS 403 Aëolus $\left.{ }^{\circledR}\right)$ using oxygen as the flowing gas for $\mathrm{Zn}_{2} \mathrm{Al}-\mathrm{CO}_{3} . \mathrm{Zn}_{2} \mathrm{Al}-\mathrm{NO}_{3}$ and $\mathrm{Zn}_{2} \mathrm{Al}-\mathrm{Cl}$ hydrotalcites were analysed under flowing nitrogen gas. The scans were accomplished at the temperature of $25^{\circ} \mathrm{C}-900 \mathrm{C}^{\circ}$ at a ramp rate of 
$5^{\circ} \mathrm{C} / \mathrm{min}$. During the sample heating to measure thermal stability, different evolved gases were considered. Mass numbers $m / z\left(18-\mathrm{H}_{2} \mathrm{O} ; 30 / 46-\mathrm{NO} / \mathrm{NO}_{2}\right.$; $36-\mathrm{HCl} ; 51-\mathrm{ClO} ; 67-\mathrm{ClO}_{2}$ or $70-\mathrm{Cl}_{2}$ and $102 / 103-\mathrm{Cl}_{2} \mathrm{O}_{2}$; and $44-\mathrm{CO}_{2}$ ) were monitored time after time.

The surface area were examined by nitrogen adsorption using an ASAP 2010 micrometer instrument.

Scanning Electrom Microscopy was carried out on the as-synthesised hydrotalcites using PhilipXL 30 Scanning Electron Microscope. The accelerating voltage was $15 \mathrm{kV}$.

\section{Results and Discussion}

The various synthesised $\mathrm{Zn}_{2} \mathrm{Al}$ hydrotalcites (with varying interlayer anions) were characterised using x-ray diffraction technique. The x-ray powder diffraction patterns are shown in Figure 1. The diffractograms showed the general characteristic reflections similar to a well crystallized hydrotalcite like compounds for all the samples. The different reflections are indexed according to the 3R symmetry (Cavaniet al., 1991; Iyi et al., 2007). The characteristic reflections of (003), (006), (009), (015), (018), and (110/113) planes were detected for $\mathrm{Zn}_{2} \mathrm{Al}-\mathrm{CO}_{3}$ and $\mathrm{Zn}_{2} \mathrm{Al}-\mathrm{Cl}$ hydrotalcites, implying that both hydrotalcites had a completely developed layer structure. The observed $\mathrm{d}_{(003)}$ reflections of the various hydrotalcites are shown in Table 1. A slight difference in the d-spacing was observed when various anions were intercalated within the interlayers. The d-spacing of $\mathrm{Zn}_{2} \mathrm{Al}-\mathrm{NO}_{3}$ hydrotalcite is larger than those of corresponding $\mathrm{Zn}_{2} \mathrm{Al}-\mathrm{CO}_{3}$ and $\mathrm{Zn}_{2} \mathrm{Al}-\mathrm{Cl}$. This may be due to ionic radius or size of the ions e.g. ionic radius of $\mathrm{CO}_{3}{ }^{2-}(1.89 \AA)$ is larger than that of $\mathrm{Cl}^{-}(1.81 \AA)$, while that of $\mathrm{NO}_{3}{ }^{-}$is $2.00 \AA$. Furthermore, carbonate anion assumes a parallel orientation within the gallery to the positive hydroxide layers, thus enhancing the hydrogen bonding between oxygen atoms and the layers. This is evident in the variation in gallery heights of the various hydrotalcites in relation to the differences in the size and symmetry of the anions (Table 1). The d-spacing of $\mathrm{Zn}_{2} \mathrm{Al}-\mathrm{CO}_{3}$ was observed at $11.86^{\circ}$, consistent with $\mathrm{d}_{(003)}$ value of $7.55 \AA$. $\mathrm{Zn}_{2} \mathrm{Al}-\mathrm{Cl}$ has similar but higher

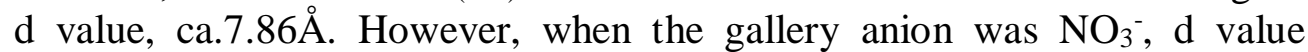
expanded to $8.98 \AA$. The XRD patterns also indicated that $\mathrm{Zn}_{2} \mathrm{Al}-\mathrm{CO}_{3}$ has sharper $d_{(003)}$ and $d_{(006)}$ reflections of the three samples, proposing a higher degree of crystallinity. $\mathrm{Zn}_{2} \mathrm{Al}-\mathrm{Clhydrotalcite}$ is least dense and showed relatively less regular stacked sheets than $\mathrm{Zn}_{2} \mathrm{AlCO}_{3}$ hydrotalcite. There is a higher disorder observed in $\mathrm{Zn}_{2} \mathrm{Al}-\mathrm{NO}_{3}$ suggesting the formation of less crystallized nanoparticles. The disturbance that occurred in the hydroxide layer of $\mathrm{Zn}_{2} \mathrm{Al}-\mathrm{NO}_{3}$ hydrotalcite resulted in the observed diffraction line broadening causing an overlap of $d_{110}$ and $d_{113}$ reflections. 


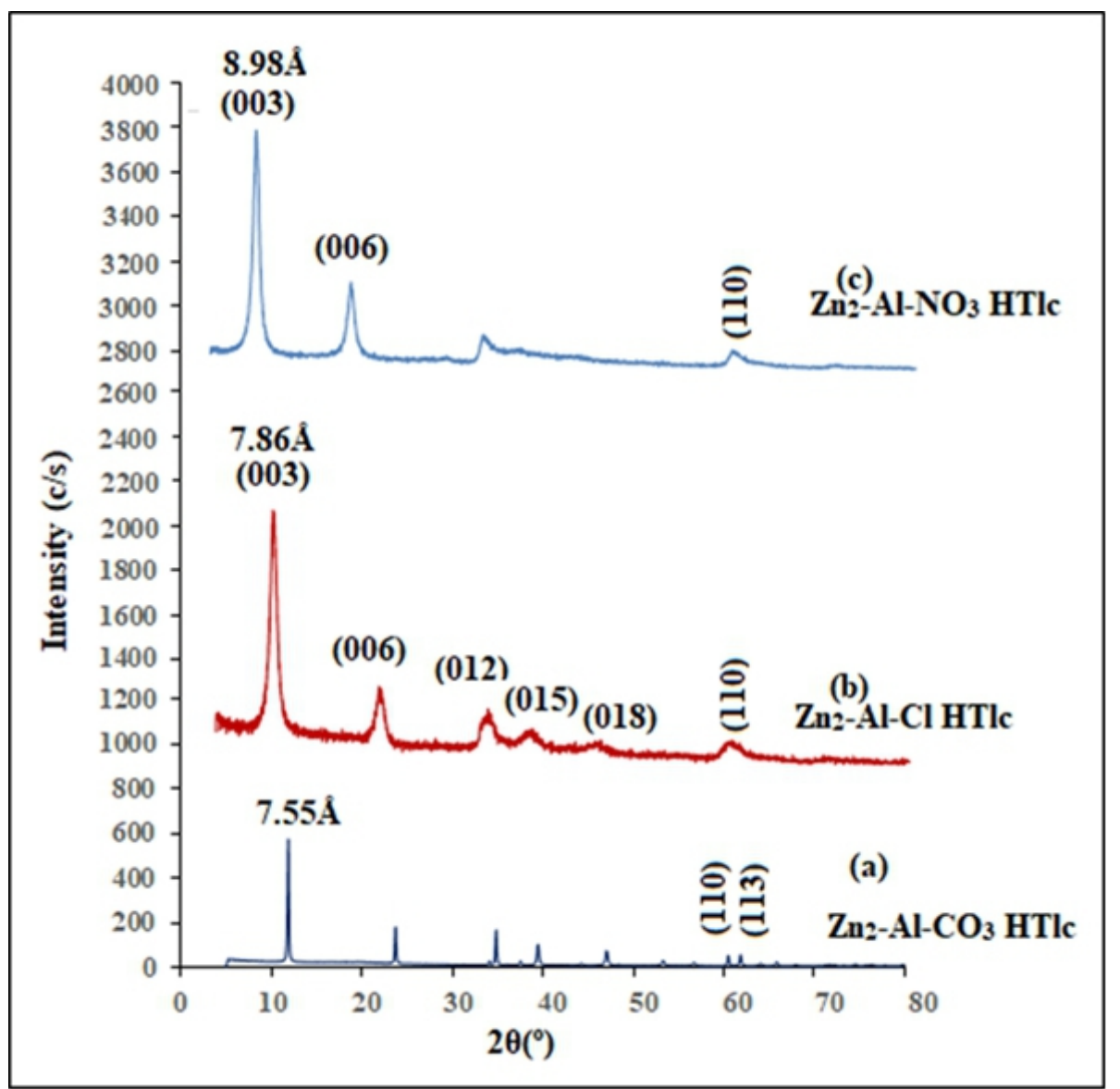

Figure 1. The $\mathrm{X}$-ray diffraction patterns for $\mathrm{Zn}_{2} \mathrm{Al}-\mathrm{A}$ hydrotalcite with varying interlayer anions. Carbonate hydrotalcite (b) Chloride hydrotalcite (c) Nitrate hydrotalcite

The elemental composition of the as-synthesised hydrotalcite-like compounds showed that the molar ratios of $\mathrm{Zn}^{2+} / \mathrm{Al}^{3+}$ are consistent with stoichiometry in mother liquor. The mole ratios and some other features of the as-synthesised hydrotalcites are shown in Table 1. The elemental ratios were converted into weight fractions of each of the oxides in the hydrotalcites, which were used to evaluate the metal composition, and the results indicated that the $\mathrm{Zn}^{2+} / \mathrm{Al}^{3+}$ mole ratios conform well to the expected ratios of these metals in the various hydrotalcites. This is a clue that precipitation of the metals were in perfect correlation to the metal ratios in starting mixtures.

FT-IR studies confirm that chloride, carbonate, and nitrate anions were intercalated into the synthesised $\mathrm{Zn}_{2} \mathrm{Al}$ hydrotalcites. The infrared spectra of the as-synthesised $\mathrm{Zn}_{2} \mathrm{Al}-\mathrm{A}$ hydrotalcites $\left(\mathrm{A}=\mathrm{CO}_{3}{ }^{2-}, \mathrm{Cl}^{-}\right.$and $\left.\mathrm{NO}_{3}{ }^{-}\right)$are presented in Figure 2. The three samples showed broad and strong absorption bands in the range of $3000 \mathrm{~cm}^{-1}$ to $3650 \mathrm{~cm}^{-1}$. This band for the $\mathrm{Zn}_{2} \mathrm{Al}-\mathrm{Cl} \mathrm{HT}$ is centered at $3332 \mathrm{~cm}^{-1}$ while $3382 \mathrm{~cm}^{-1}$ for the carbonate and $3284 \mathrm{~cm}^{-1}$ for the 
nitrate hydrotalcites respectively. These bands are due to hydroxyl stretching vibration of the surface water and interlayer water molecules.

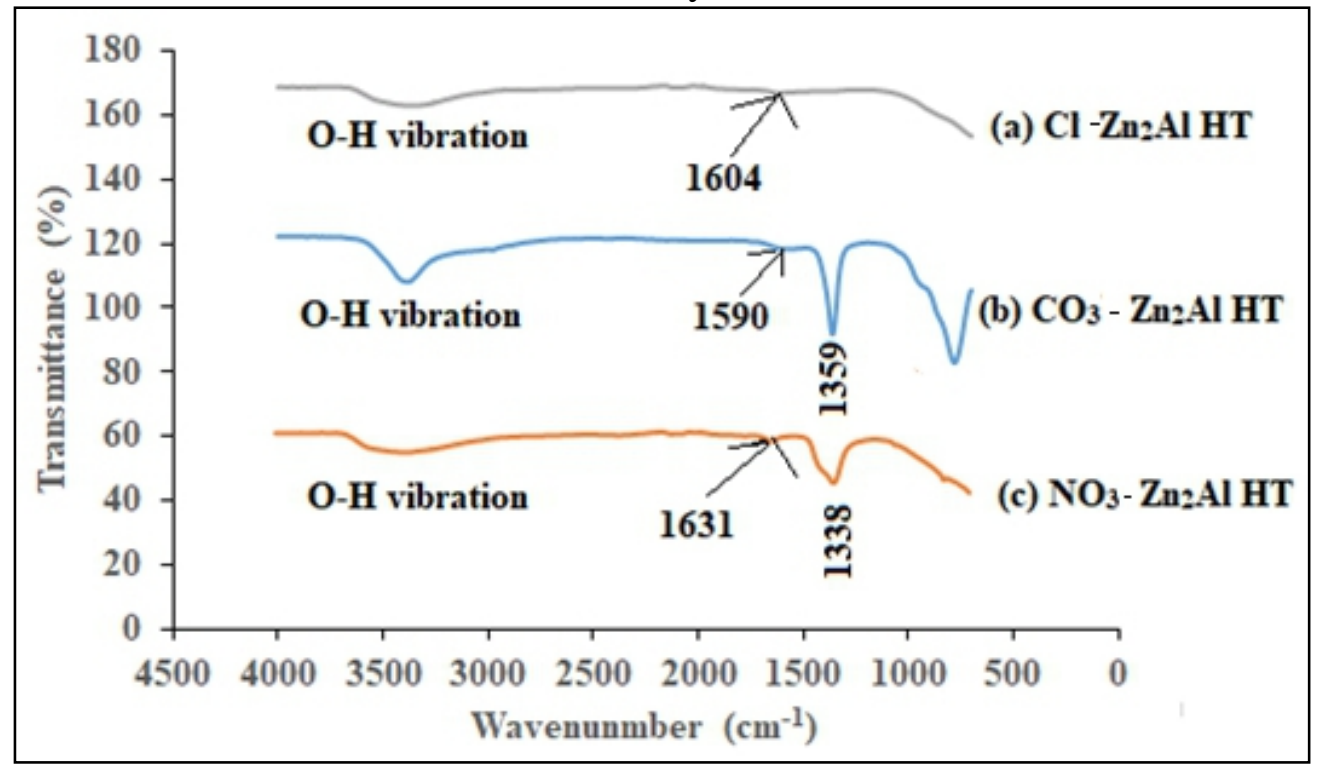

Figure 2. FTIR Spectra of (a) Chloride $\mathrm{Zn}_{2} \mathrm{Al}$ HT (b) carbonate $\mathrm{Zn}_{2} \mathrm{Al}$ HT

(c) Nitrate $\mathrm{Zn}_{2} \mathrm{Al} \mathrm{HT}$

The band is relatively narrower for the carbonate hydrotalcite, which may suggest the strength of hydrogen bonding interaction of the carbonate anion in the interlayer of $\mathrm{Zn}_{2} \mathrm{Al}-\mathrm{CO}_{3}$ hydrotalcite matrix. A prominent sharp band at approximately $1359 \mathrm{~cm}^{-1}$ (for the $\mathrm{Zn}_{2} \mathrm{Al}-\mathrm{CO}_{3} \mathrm{HT}$ ) showed carbonate in the interlayer space. Whereas for the nitrate hydrotalcite, the prominent sharp band occurred at $1338 \mathrm{~cm}^{-1}$ with a shoulder at $1394 \mathrm{~cm}^{-1}$. This shows that the intercalated anion is nitrate in the interlayer region but slightly contaminated with $\mathrm{CO}_{3}{ }^{2-}$ due to the slight asymmetry to the nitrate band. Despite the precaution maintained during synthesis, sample was still found contaminated with atmospheric carbon dioxide. This is because hydrotalcite has strong affinity towards carbon dioxide. Vibration ascribed to $\mathrm{O}-\mathrm{H}$ bending mode of interlayer water is seen at $1631 \mathrm{~cm}^{-1}$ for the nitrate hydrotalcite, $1590 \mathrm{~cm}^{-1}$ for the carbonate, and $1604 \mathrm{~cm}^{-1}$ for the chloride hydrotalcite respectively. The observed variations in the shifting of bands to higher frequency may be as a result of differences in the hydrogen bonding strength, which existed between the layers and interlayers of the various hydrotalcites. Also, it may be attributed to the differences in crystallinity and structural order. 
Table 1. Mole ratio, $\left.d_{(003)}\right)(\AA), d_{(006}(\AA)$, Gallery height $(\AA)$, and Surface area $\left(\mathrm{m}^{2} / \mathrm{g}\right)$ of the synthesised hydrotalcites

\begin{tabular}{|c|c|c|c|c|c|c|c|}
\hline $\begin{array}{l}\text { Prepared } \\
\text { hydrotalcies }\end{array}$ & $\begin{array}{l}\text { Wt \% } \\
\text { of } \\
\mathrm{ZnO}\end{array}$ & $\begin{array}{l}\mathrm{Wt} \% \\
\text { of } \\
\mathrm{Al}_{2} \mathrm{O}_{3}\end{array}$ & $\begin{array}{l}\mathrm{Zn} / \mathrm{Al} \\
\text { mole } \\
\text { ratio }\end{array}$ & $\begin{array}{l}d_{(003)} \stackrel{\AA}{(d-s p a c i n g)} \\
\text { (d-s }\end{array}$ & $\mathbf{d}_{(006)} \stackrel{A}{ }$ & $\begin{array}{l}\text { Gallery } \\
\text { Height } \\
(\AA)\end{array}$ & $\mathrm{SA}\left(\mathrm{m}^{2} / \mathrm{g}\right)$ \\
\hline $\mathrm{Zn}_{2} \mathrm{Al}-\mathrm{CO}_{3}$ & 69.90 & 20.10 & $2.18: 1$ & 7.55 & 3.77 & 2.75 & $13.23 \pm 0.032$ \\
\hline $\mathrm{Zn}_{2} \mathrm{Al}-\mathrm{Cl}$ & 52.29 & 16.36 & $2.05: 1$ & 7.86 & 3.90 & 3.06 & $0.40 \pm 0.005$ \\
\hline $\mathrm{Zn}_{2} \mathrm{Al}-\mathrm{NO}_{3}$ & 54.88 & 16.92 & 2.03:1 & 8.98 & 4.47 & 4.18 & $0.21 \pm 0.006$ \\
\hline
\end{tabular}
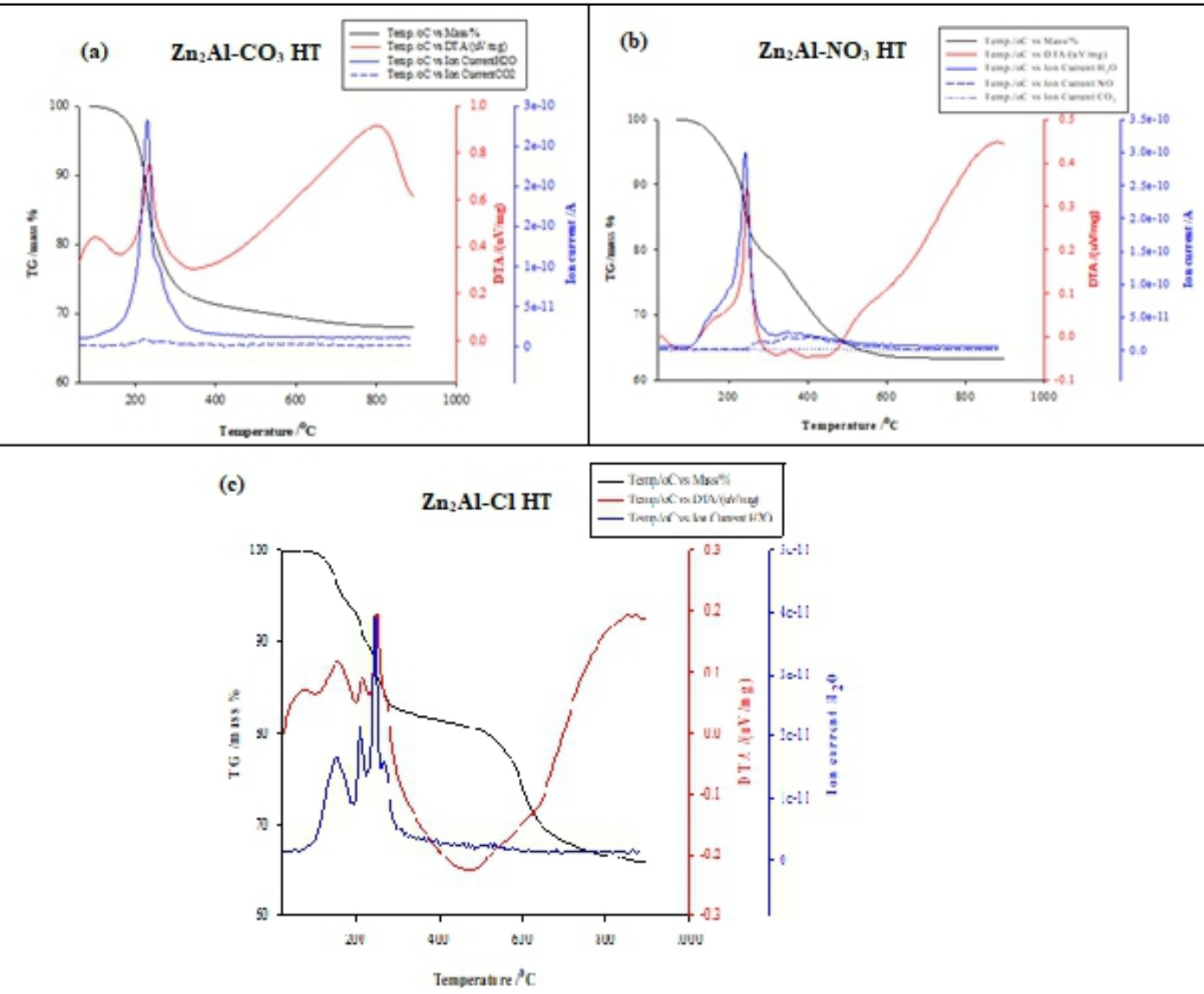

Figure 3. TG, DTA, and gas evolution profile for $\mathrm{Zn}_{2} \mathrm{Al}-\mathrm{CO}_{3}, \mathrm{Zn}_{2} \mathrm{Al}-\mathrm{NO}_{3}$, and $\mathrm{Zn}_{2} \mathrm{Al}-\mathrm{Cl}$ hydrotalcites

The TG-DTA and ion current profile of $\mathrm{Zn}_{2} \mathrm{Al}-\mathrm{CO}_{3}, \mathrm{Zn}_{2} \mathrm{Al}-\mathrm{Cl}$, and $\mathrm{Zn}_{2} \mathrm{Al}-\mathrm{NO}_{3}$ are presented in Figure 3. The thermogravimetric and differential thermal analysis showed that $\mathrm{Zn}_{2} \mathrm{Al}-\mathrm{CO}_{3}$ hydrotalcite has two palpable weight loss processes. The crystallite water (fixed water, bound to the external surface and interlamella) was eliminated around $140^{\circ} \mathrm{C}$, while the simultaneous removal of hydroxyl groups from the layers and carbonate anion from the 
interlayer space or the internal galleries causing the breakdown of the structure happened around $235^{\circ} \mathrm{C}$. The evolution of adsorbed water was completed by $350^{\circ} \mathrm{C}$. The ion current curve (mass spectrometry analysis) showed that the evolution of $\mathrm{H}_{2} \mathrm{O}$ was in a single step at $231^{\circ} \mathrm{C}$, and $\mathrm{CO}_{2}$ from carbonate breakdown was at $225^{\circ} \mathrm{C}$. Complete breakdown of the hydrotalcite happened between $500^{\circ} \mathrm{C}$ to $900^{\circ} \mathrm{C}$, leading to the emergence of defect metal oxides $\left(\mathrm{Zn}_{2} \mathrm{AlO}_{3}\right.$ spinel), which gradually gained stability as the thermal temperature rises, thus, giving a total wt. loss of $32 \%$.

The $\mathrm{Zn}_{2} \mathrm{Al}-\mathrm{NO}_{3}$ hydrotalcite releases its fixed water at about $215^{\circ} \mathrm{C}$ and the $\mathrm{OH}^{-}$from the hydroxide layers around $246^{\circ} \mathrm{C}$ and $352^{\circ} \mathrm{C}$. The nitrate anions were lost at $354^{\circ} \mathrm{C}$ and evolution was concluded at $354^{\circ} \mathrm{C}$. Total breakdown leading to the spinel happened around $520^{\circ} \mathrm{C}-900^{\circ} \mathrm{C}$ resulting to a total wt. loss of $36.7 \%$.

$\mathrm{Zn}_{2} \mathrm{Al}-\mathrm{Cl}$ hydrotalcite showed the first wt. loss and elimination of surface water at $150^{\circ} \mathrm{C}$ and $210^{\circ} \mathrm{C}$. The second wt. loss can be assigned to the loss of fixed water from the metal hydroxide layers together with decomposition of the interlayer chloride anion resulting into a collapse of the structure. However, the mass spectrometry analysis of outflowing gases did not detect chloride evolution. This may be due to the low set temperature of the QMS furnace $\left(200^{\circ} \mathrm{C}\right)$. However, Barriga and co-workers reported that chloride ions were removed from their own chloride hydrotalcite as $\mathrm{HCl}$ at around $600^{\circ} \mathrm{C}$ alongside dehydroxylation of the hydroxide layers happening between $400-600^{\circ} \mathrm{C}$ (Barriga et al., 1998). Heat treatment of $\mathrm{Zn}_{2} \mathrm{Al}-\mathrm{Cl}$ up to $900^{\circ} \mathrm{C}$ gave a total mass loss of $34.3 \%$ with respect to the initial sample weight.

The surface area of the hydrotalcites $\left(\mathrm{Zn}_{2} \mathrm{Al}-\mathrm{A}\right.$ where $\mathrm{A}=\mathrm{CO}_{3}{ }^{2-}, \mathrm{NO}_{3}{ }^{-}$ or $\mathrm{Cl}^{-}$) showed surface area values in the range of $0.20-15 \mathrm{~m}^{2} /$ gand as shown in Table 1. The carbonate form showed highest surface area $\mathrm{Zn}_{2} \mathrm{Al}-\mathrm{CO}_{3}-\mathrm{HT}$ $\left(13.23 \pm 0.032 \mathrm{~m}^{2} / \mathrm{g}\right)$ while $\mathrm{Zn}_{2} \mathrm{Al}-\mathrm{NO}_{3}$-HTlc showed the lowest value of 0.21 $\pm 0.01 \mathrm{~m}^{2} / \mathrm{g}$. This is consistent with XRD result which showed crystallinity and unit cell dimension in increasing order of $\mathrm{Zn}_{2} \mathrm{Al}-\mathrm{CO}_{3}>\mathrm{Zn} 2 \mathrm{Al}-\mathrm{Cl}>\mathrm{Zn}_{2} \mathrm{Al}-\mathrm{NO}_{3}$. 


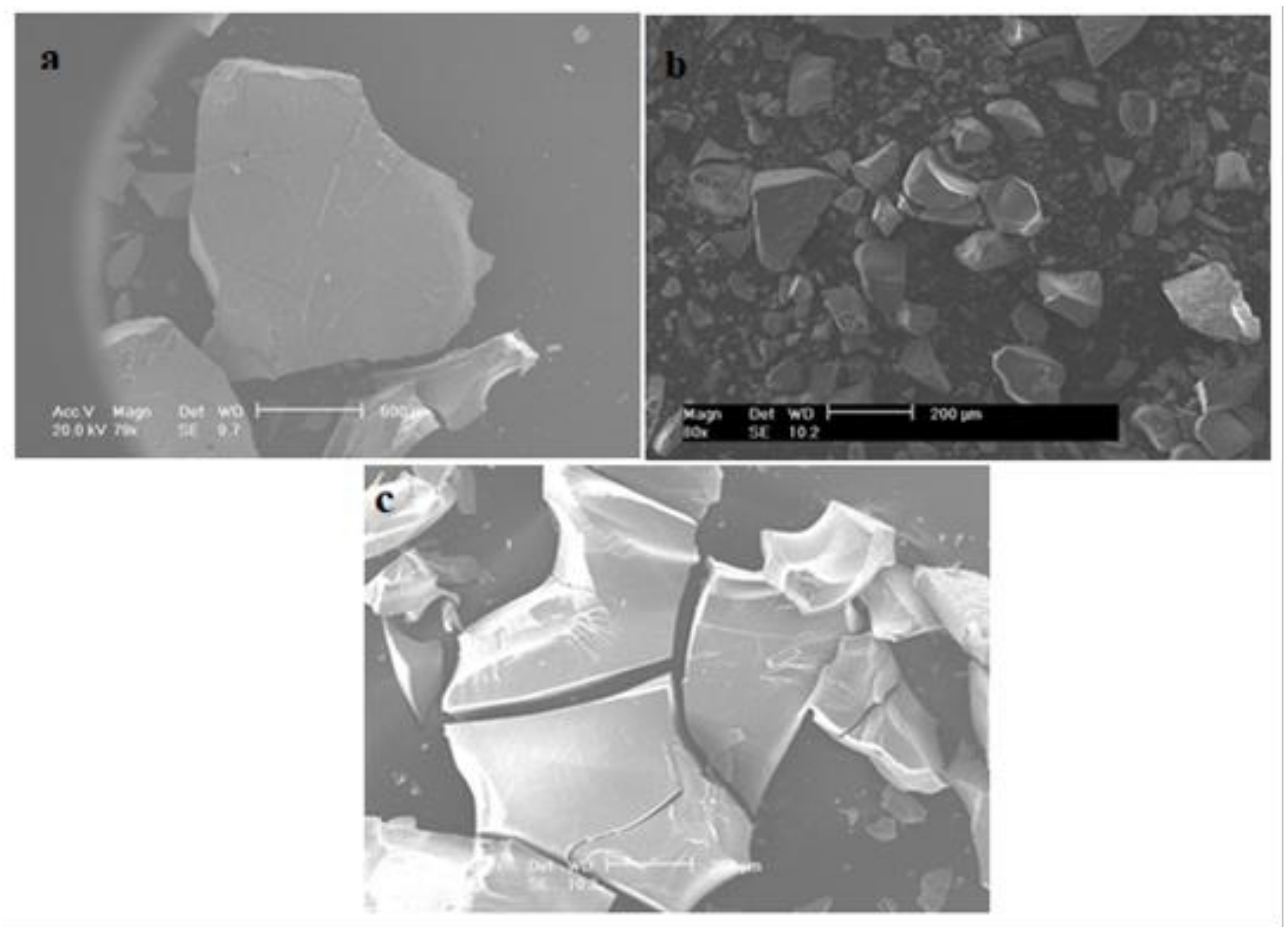

Figure 4. SEM images of (a) $\mathrm{Zn}_{2} \mathrm{Al}-\mathrm{Cl}$, (b) $\mathrm{Zn}_{2} \mathrm{Al}-\mathrm{CO}_{3}$, and (c) $\mathrm{Zn}_{2} \mathrm{Al}-\mathrm{NO}_{3}$ Hydrotalcites

The morphology of the as-synthesised $\mathrm{Zn}_{2} \mathrm{Al}-\mathrm{Cl}, \mathrm{Zn}_{2} \mathrm{Al}-\mathrm{CO}_{3}$, and $\mathrm{Zn}_{2} \mathrm{Al}-\mathrm{NO}_{3}$ Hydrotalcites are presented in Figure 4. They showed hexagonal nano particles. Figure 4(a) and 4(b) reveals that $\mathrm{Zn}_{2} \mathrm{Al}-\mathrm{Cl}$ and $\mathrm{Zn}_{2} \mathrm{Al}-\mathrm{CO}_{3}$ formed hexagonal nano particles with regular shapes. The layers have a diameter of over several hundred nanometers and a thickness of over some tens of nanometers, not observed for $\mathrm{Zn}_{2} \mathrm{Al}-\mathrm{NO}_{3}$, propounding that the crystallinity of this hydrotalcites is lower than the crystalline degree of $\mathrm{Zn}_{2} \mathrm{Al}$ $\mathrm{Cl}$ and $\mathrm{Zn}_{2} \mathrm{Al}-\mathrm{CO}_{3}$. This is compatible with the $\mathrm{x}$-ray diffraction results.

\section{Conclusion}

Hydrotalcite-like compounds of $\mathrm{Zn}^{2+/} \mathrm{Al}^{3+}$ cations in the hydroxide layers with different anions, carbonate, chloride, and nitrate in the interlamellar space were successfully synthesised by co-precipitation method.

The carbonate hydrotalcite yielded most dense nano particles, with more regular stacked sheets and higher structural order with higher degree of crystallinity.

Variance of interlamellar anions within the interlayer spaces has influence on the specific properties of the hydrotalcites as revealed by the range of characteristic techniques employed in this study. The nitrate hydrotalcite were less crystalline, has less stacking order, and the 
decomposition temperatures were higher with nitrate and chloride hydrotalcites.

As with most hydrotalcites, they undergo three decomposition stages; first to loss surface water and interlayer water, second stage involves dehydroxylation and removal of the interlayer anions both happening simultaneously, and the third is the decomposition that gave the mixed metal oxides (spinel) which maintained a memory effect of the starting structure. This is a vital property of hydrotalcites that influences the preparation and possible applications. The nature and type of anion in the interlamella can influence the properties of hydrotalcites.

\section{Acknowledgement}

The authors are thankful to the University of Birmingham (West Midlands Centre for Advanced Material Project 1), Advantage West Midlands (AWM) (ERDF), and also the Education Trust Fund of Nigeria for their support through a grant to one of the authors (SIO).

\section{References:}

1. Barriga, C., Jones, W., Malet, P., Rives, V. \& Ulibarri, M. A. (1998). Synthesis and Characterization of Polyoxovanadate-Pillared Zn-Al Layered Double Hydroxides: An X-ray Absorption and Diffraction Study. Inorganic Chemistry, 37(8), pp 1812-1820. doi:10.1021/ic9709133.

2. Basahel, S. N., Al-Thabaiti, S. A., Narasimharao, K., Ahmed, N. S. \& Mokhtar, M. (2014). Nanostructured Mg-Al Hydrotalcite as Catalyst for Fine Chemical Synthesis. Journal of Nanoscience and Nanotechnology, 14(2), pp 1931-1946. doi:10.1166/jnn.2014.9193

3. Birgül, Z.K. \& Ahmet, A. (2012). Layered Double Hydroxides Multifunctional Nanomaterials. Chemical Papers, 66(1), pp.110.doi.org/10.2478/s11696-011-0100-8.

4. Cavani, F., Trifirò, F. \& Vaccari, A. (1991). Hydrotalcite-type Anionic Clays: Preparation, Properties and Applications. Catalysis Today, 11(2), pp 173-301. doi.org/10.1016/0920-5861(91)80068-K.

5. El Hassani, K, Beakou, B.H., Kalnina, D., Oukani, E. \& Anouar, A. (2017). Effect of Morphological Properties of Layered Double Hydroxides on Adsorption of Azo dye Methyl Orange: A Comparative Study. Applied Clay Science 140, pp 124-131. doi.org/10.1016/j.clay.2017.02.010.

6. Evans, D. G. \& Duan, X. (2006). Preparation of Layered Double Hydroxides and their Applications as Additives in Polymers, as Precursors to Magnetic Materials and in Biology and Medicine, Chemical Communication, 5, pp 485-496. 10.1039/B510313B. 
7. Iyi, N., Fuji, K., Okamoto K. \& Sasaki, T. (2007). Factors influencing the hydration of Layered Double Hydroxides (LDHs) and the appearance of an intermediate second staging phase. Applied ClayScience 35(3-4), pp218-227.

8. Li, F. \& Duan, X. (2006). Applications of Layered Double Hydroxides. In: Duan, X., Evans, D.G. (Eds.), Structure and Bonding. Vol. 119. Springer, New York, NY, USA.doi.org/10.1007/430-007.

9. Omonmhenle, S.I. \& Shannon, I.J. (2016). Synthesis and Characterisation of Surfactant enhanced $\mathrm{Mg}-\mathrm{Al}$ Hydrotalcite-like Compounds as Potential 2-Chlorophenol Scavengers, Applied Clay Science, 127-128, pp 88-94. doi.org/10.1016/j.clay.2016.03.033.

10. Pshinko, G.N. (2013). Layered Double Hydroxides as Effective Adsorbents for U (VI) and toxic heavy metals removal from aqueous media. Journal of Chemistry, pp 1-9. doi.org/10.1155/2013/347178.

11. Rives, V. (2001). Layered Double Hydroxides: Present and Future. Nova Science Publishers, New York, NY, USA.

12. Sulekha, M.S. (2016). Nanotechnology for Waste Water Treatment. International Journal of Chemical Studies 4(2), pp 22-24.

13. You, Y., Vance, G.F. \& Zhao, H. (2001). Selenium adsorption on Mg$\mathrm{Al}$ and $\mathrm{Zn}-\mathrm{Al}$ layered double hydroxides. Applied Clay Science, 20(12), pp.13-25.

14. Zümreoglu-Karan, B. \& Ay, A. (2012). Layered Double Hydroxides Multifunctional Nanomaterials. Chemical Papers, 66(1), pp 1-10. doi:10.2478/s11696-011-0100-8. 